\title{
Analisa Performa Bisnis Di Desa Wisata Kandri Semarang Berdasarkan Karakteristik Pelaku UMKM
}

\author{
Syaiful Ade Septemuryantoro*1 \\ ${ }^{1}$ Universitas Dian Nuswantoro \\ E-mail: syaiful.ade@dsn.dinus.ac.id
}

\begin{abstract}
Tourism village as an alternative tourism for tourists who can provide a source of income. The main problem is the difficulty of managing and planning finances. The purpose of the research is to examine business performance based on the characteristics of the respondents which including gender, age, and level of education. The total sample taken is 50 respondents. Data is retrieved through questionnaire. The method of analysis used is a different test one way ANOVA analysis with a significance level of 5\%. The implication of this research is that business performance is not influenced by respondent characteristics (gender, age, education level) so that it is easy to develop MSME activities in the future.
\end{abstract}

Keywords: Business Performance, Tourism Village, Characterictics of Respondents

Desa wisata sebagai alternatif wisata bagi wisatawan mampu menghadirkan sumber pendapatan baru bagi masyarakat di destinasi wisata tersebut. Permasalahan tentang merencanakan dan mengelola keuangan menjadi salah satu tantangan terberat yang harus segera diatasi supaya kegiatan usaha UMKM di desa wisata tersebut dapat berlangsung secara optimal. Tujuan penelitian yaitu menguji performa bisnis bedasarkan karateristik responden pelaku UMKM antara lain jenis kelamin, usia, dan tingkat pendidikan. Pengambilan sampel sebanyak 50 responden pelaku usaha UMKM di desa wisata Kandri dengan menggunakan kuesioner. Metode yang digunakan adalah analisa one way ANOVA dengan taraf signifikansi 5\%. Implikasi dari penelitian ini bahwa performa bisnis tidak dipengaruhi oleh karakteristik responden (jenis kelamin, usia, tingkat pendidikan) sehingga mudah untuk mengembangkan kegiatan UMKM di masa yang akan datang.

Kata kunci: Performa Bisnis, Desa Wisata, Karakteristik responden

\section{PENDAHULUAN}

Pertumbuhan bisnis pada sektor unggulan pariwisata telah dirasakan manfaatnya bagi para pelaku industri pariwisata, hal ini dikarenakan pada sektor pariwisata mempunyai karakter yang mempunyai sifat multiplier effect. Pariwisata menciptakan banyak bisnis yang mempunyai potensi yang tinggi sehingga dapat terus dikembangkan, seiring dengan pergerakan pariwisata Indonesia yang mampu mendukung ekonomi Indonesia sehingga 
pemerintah melalui Kemenparekraf mengembangkan potensi wisata terutama desa wisata. Desa wisata yang mempunyai keunggulan dalam menunjang pariwisata antara lain keindahan desa wisata yang berupa alam, adat istiadat, pertanian, perkebunan, pertambangan, bentang alam, gunung, serta budaya masyarakat sekitar. Salah satu syarat yang diminati oleh wisatawan yaitu destinasi wisata tersebut aman dan nyaman saat dikunjungi. Peranan destinasi wisata dalam mendukung sektor pariwisata memberikan nilai tambah kepada wisatawan baik domestik maupun mancanegara sehingga dapat meningkatkan pendapatan masyarakat sekitar. Kesempatan kerja dengan membuka bisnis yang berkaitan erat dengan pariwisata mampu menjadikan masyarakat sekitar destinasi wisata tersebut mempunyai andil dalam mengembangkan potensi pariwisata tersebut.

Bisnis yang bersumber pada kegiatan pariwisata dapat dilakukan oleh setiap orang yang mempunyai kemampuan dalam hal mengelola bisnis. Setiap orang yang mampu menjalankan bisnis bergantung pada kemampuannya sendiri dengan kata lain dengan adanya desa wisata yang telah dicanangkan oleh pemerintah melalui Kemenparekraf. Pada saat ini desa wisata telah menjadi magnet bagi wisatawan yang menginginkan suasana yang berbeda, saat ini desa wisata telah dikenal oleh masyarakat berkat adanya media sosial yang mengenalkan keindahan alam desa wisata tersebut. Adapun permasalahan yang timbul yaitu kurang mampunya masyarakat dalam mengelola potensi wisata yang ada di desa tersebut. Desa wisata yang ada di Semarang menjadi salah satu destinasi alternatif wisatawan, dengan adanya desa wisata tersebut menjadi sumber penghasilan masyarakat yang ada di destinasi wisata tersebut. Desa wisata sebagai alternatif wisata bagi wisatawan mampu menghadirkan sumber pendapatan baru bagi masyarakat di destinasi wisata tersebut. Masyarakat yang ada di detinasi wisata tersebut mampu mengembangkan potensi yang ada di destinasi wisata tersebut. Salah satu dari kegiatan bisnis tersebut yaitu membuat dan menjual bentuk kerajinan yang ada serta menjadikan salah satu alternatif buah tangan untuk dibawa pulang wisatawan setelah berkunjung di desa wisata tersebut. Pemerintah melalui Kemenparekraf harus memperhatikan potensi desa wisata serta adanya perhatian dari pemangku kebijakan setempat. Menurut Septemuryantoro, 2017 bahwa pariwisata di Indonesia tentunya sangat bergantung kepada budaya yang ada pada destinasi wisata. Indonesia mempunyai banyak keindahan dan keberanekaragaman adat istiadat serta budaya yang mampu menarik calon wisatawan. Adapun destinasi wisata yang berhubungan erat dengan budaya dan adat istiadat dengan mudah ditemui di Indonesia. Pengawasan terhadap destinasi wisata yang akan dibuka tentunya memerlukan kerjasama yang baik serta pengawasan dari dinas yang terkait diantaranya dinas pariwisata dan pemerintah daerah yang nantinya akan berperan secara langsung dalam mengawasi jalannya kegiatan pembukaan destinasi wisata.

Menurut Septemuryantoro, 2020 mengatakan bahwa kekayaan alam Indonesia yang sangat melimpah akan tetapi belum dimanfaatkan secara maksimal sehingga perlu peran serta sumberdaya yang mampu mengolah potensi tersebut. Potensi wisata di kota Semarang umumnya sangat beragam baik pertumbuhan usaha yang berkaitan dengan wisata maupun secara umum sehingga menarik untuk dikembangkan. Keberadaan desa wisata yang ada di Semarang mampu meningkatkan sumber pendapatan masyarakat setempat. Kegiatan wisata yang ada tentunya mempunyai banyak tantangan salah satu diantaranya adalah kurangnya modal sehingga perlu adanya bantuan dalam bentuk pinjaman dengan mengandeng koperasi atau lembaga keuanga/ perbankan. Adanya industri UMKM yang tentunya membutuhkan modal untuk mengembangkan usahanya, dengan adanya desa wisata 
tentunya memberikan banyak keuntungan serta kontribusi yang baik bagi pendapatan masyarakat maupun pendapatan pemerintah daerah. Adapun peran pemerintah daerah harus meningkatkan akses secara mudah bagi industri UMKM dalam mendapatkan modal, selain adanya kurangnya modal umumnya terdapat tantangan lain yaitu pengelolaan keuangan. Pelaku UMKM biasanya kurang memiliki pengetahuan dan wawasan dalam mengelola keuangan, seperti misalnya pelaku UMKM mempunyai warung atau toko kelontong yang menjual kebutuhan sehari-hari maupun kebutuhan wisatawan yang belum mampu memisahkan keuangan toko dengan pedapatan pribadi sehingga banyak yang tutup maupun kehabisan modal karena tidak mampunyai kemmapuan dalam mengelola keuangan.

Pelaku UMKM kurang mampu dalam mengelola keuangan tentunya berdampak pada laporan keuangan yang tidak tercatat atau terbukukan, sehingga diperlukan pelatihan yang berkaitan erat dengan manajemen keuangan tersebut. Laporan keuangan UMKM biasanya menjadi salah stau syarat dalam mengajukan pinjaman di perbankan, sehingga dengan adanya laporan keuangan yang baik dari pelaku UMKM tentunya dapat membuka akses yang mudah dalam dunia perbankan dengan melihat kemampuan keuangan UMKM dalam membayar kredit yang akan diberikan oleh pihak perbankan. Beberapa potensi yang umumnya ditemukan oleh desa wisata umumnya adalah potensi desa, akses modal serta kemampuan merencanakan keuangan yang baik. Adanya permasalahan tentang merencanakan dan mengelola keuangan menjadi salah satu tantangan terberat yang harus segera diatasi supaya kegiatan usaha UMKM di desa wisata tersebut dapat berlangsung secara optimal. Potensi desa yang sedimikian rupa dengan segala permasalahan yang ada di dalamnya tentunya harus dimanfaatkan secara baik sehingga menimbulkan efek jangka panjang yang baik serta berkelanjutan.

Desa wisata merupakan salah satu bentuk komunitas masyarakat yang di dalamnya terdiri atas masyarakat yang mendiami daerah tertentu serta adanya bentuk keterikatan antara satu dengan yang lain, serta adanya kesadaran dan bentuk kepedulian masyarakat dalam memajukan desa tersebut. Pemberdayaan masyarakat sekitar dengan mengoptimalkan potensi yang dimiliki mampu mewujudkan sapta pesona yang menghasilkan pemerataan pembangunan yang ada di daerah serta memajukan dan meningkatkan kesejahteraan masyarakat sekitar. (Kemenparekraf RI, 2019). Desa wisata Kandri merupakan salah satu desa wisata yang mempunyai potensi sangat baik di Semarang. Adanya perhatian dari pemerintah daerah tentunya akan berdampak sangat baik demi keberlangsungan desa wisata tersebut. Potensi dan pertumbuhan ekonomi desa wisata sangat besar, sehingga diharapkan mampu mendorong perekonomian yang ada di desa wisata tersebut. Peran pemerintah dengan menjadi pendamping kegiatan UMKM sangat penting terutama keterampilan atau mengadakan pelatihan dalam hal laporan keuangan UMKM. Apabila dilihat pada potensi yang ada di desa wisata tentunya mampu menjadi desa wisata unggulan yang mampu menggerakkan perekonomian masyarakat sekitar. Akan tetapi timbul permasalahan dalam mengembangkan kinerja bisnis yang berkelanjutan sehingga permasalahan yang timbul umumnya desa wisata menjadi stagnan dan tidak berkembang dan lama kelamaan akan tutup. Melihat banyak desa wisata di beberapa daerah yang dulunya aktif mempromosikan serta menjadi salah satu daya tarik dalam mendatangkan wisatawan sekarang sudah tidak tampak lagi atau bahkan dapat dikatakan mati suri. Pengelolaan dalam mengurus desa wisata membutuhkan usaha yang sangat besar, tidak semua masyarakat maupun pelaku UMKM dapat bertahan seiring dengan berjalannya 
waktu dengan aktivitas yang cenderung tidak ada sehingga beberapa dari desa wisata tersebut membubarkan diri.

Permasahan internal dalam mengelola desa wisata tentunya menjadi hal yang menbutuhkan konsentrasi yang maksimal, akan tetapi permasalahan yang timbul salah stau diantaranya adalah ketidakmampuan pengelola desa wisata dalam melahirkan program wisata yang tidak membosankan, sehingga dapat menarik terus kunjungan wisatawan. Permasalahan tersebut yang menjadikan banyak desa wisata tidak berkembang bahkan tutup, selain itu terdapat permasalahan internal antara sesama anggota kelompok UMKM baik dalam hal keuangan. Permasalahan keuangan menjadikan kelompok UMKM tersebut menjadi tidak lagi solid sehingga timbul permasalahan lain, desa wisata bergantung pada keaktifan pengelola sehingga potensi UMKM yang terdapat di dalamnya juga akan berpengaruh. Pada saat desa wisata mengalami penurunan maka potensi UMKM juga akan mengalami penurunan. Potensi UMKM bergantung kepada wisatawan, UMKM yang ada di desa wisata akan mati seiring dengan penurunan jumlah wisatawan yang datang. Hal ini menjadi tantangan terbesar untuk UMKM untuk terus berkembang, meskipun potensi untuk berkembang membutuhkan banyak tantangan seiring dengan target yang akan dicapai. Suatu kinerja bisnis menunjukkan bahwa di dalamnya terdapat performa bisnis suatu usaha.

Beberapa usaha UMKM memiliki performa bisnis yang baik, tetapi terdapat beberapa permasalahan, berdasarkan permasalahan tersebut maka penelitian tersebut melihat beberapa faktor yang mempengaruhi performa bisnis pada desa wisata Kandri Semarang berdasarkan karakteristik responden. Pengujian performa bisnis yang berdasarkan karateristik responden meliputi jenis kelamin, usia, tingkat pendidikan apakah mempengaruhi perfoma bisnis UMKM.

\section{KAJIAN TEORETIK}

UMKM yang ada di Indonesia menjadi salah satu sektor yang diprioritaskan pada sektor pengembangan ekonomi di Indonesia, UMKM mempunyai peran sebagai tulang punggung yang mempunyai tujuan untuk mengurangi kemiskinan dengan mengurangi kesenjangan antara golongan pendapatan serta dengan pelaku usaha. Adanya UMKM mampu memberikan kontribusi yang positif bagi percepatan sektor yang mendukung perekonomian suatu daerah dan meningkatkan ketahanan nasional, pengembangan UMKM yang berbasis ekonomi kreatif mampu menciptakan sumber penghasilan yang baik dan tentunya mengurangi angka pengangguran (Kurniawan, 2011)

(Hasanah et al, 2020) mengatakan bahwa pendapatan UMKM sering dipengaruhi oleh teknologi dan modal perusahaan. Modal dan teknologi yang digunakan untuk mendukung pendapatan UMKM umumnya bergantung pada aplikasi, sehingga semakin banyak teknologi yang digunakan maka semakin tinggi pendapatan perusahaan begitupula sebaliknya. Faktor pendidikan yang disurvei tidak berpengaruh signifikan terhadap pendapatan, sehingga pegawai dengan latar belakang rendah atau berpendidikan baik memiliki kesempatan yang sama dan setara dalam pertumbuhan usaha UMKM. Menurut (Dewi dan Utari, 2014) mengatakan bahwa tingkat modal perusahaan, tingkat pendidikan dan teknologi memiliki dampak yang signifikan terhadap pendapatan UMKM. Modal yang dibutuhkan untuk mendukung UMKM menunjukkan bahwa semakin banyak modal yang mereka gunakan, semakin banyak uang yang dihasilkan UMKM. Teknologi yang digunakan untuk mendukung UMKM memiliki dampak positif yang signifikan terhadap pendapatan UMKM. (Ardiana et al, 2010) menyatakan bahwa promosi tentang pengembangan sektor 
wirausaha baru terkait dengan upaya menumbuhkan lingkungan bisnis yang kondusif, menumbuhkan persiapan masyarakat untuk berwirausaha dan memberdayakan masyarakat dalam berwirausaha. Namun, pengembangan UMKM harus melibatkan pengembangan sumber daya manusia (SDM) dalam beberapa hal. Perlu adanya pengembangan sumber daya manusia bagi pekerja dan UMKM sebagai pengusaha. Kewirausahaan dan peningkatan produktivitas yang didukung oleh perkembangan teknologi penting untuk difokuskan pada penguatan sumber daya manusia.

Undang-undang No. 20 Tahun 2008 yang telah disahkan oleh pemerintah dengan isi tentang pengembangan UMKM, perluasan iklan komersial mengarah pada pengembangan UMKM, peningkatan produktivitas dan daya saing UMKM, UMKM dalam lingkup mikro Didirikan termasuk peningkatan keterampilan bisnis perusahaan. UMKM dapat meningkatkan kapasitas sumber daya manusia, meningkatkan citra UMKM, mengembangkan efektivitas yang terintegrasi dari keterlibatan masyarakat dan pemangku kepentingan dalam pemberdayaan UMKM. Desa wisata Kandri mempunyai beberapa wisata digital yang memanfatkan halaman pekarangan dengan pemandangan dataran tinggi dengan latar belakang waduk Jatibarang sehingga dimanfaatkan untuk wisata digital, desa wisata ini berdiri atas keputusan Walikota Semarang no 566/407 tahun 2012 tentang penetapan kelurahan Kandri dan kelurahan Nongkosawit sebagai desa wisata di kota Semarang. (https://kandri.semarangkota.go.id/, diakses 21 Juni 2021). Wisata digital yang terdapat di desa wisata Kandri antara lain :

1.Wisata digital dengan tema Balon Udara, wisata ini berupa replika balon udara dengan menggunakan bahan bambu dan kain yang dibentuk menyerupai balon udara sehingga pengunjung dapat berswafoto dengan tema tersebut.

2.Wisata digital dengan tema Bunga Sakura, wisata digital ini mengadopsi replika bnnga sakura Jepang yang berbahan dasar kain dan cat warna warni sehingga menyerupai pohon sakura.

3.Wisata digital dengan tema Bunga Bidadari, wisata digital ini mengadopsi replika bunga besar khas bidadari yang sedang mekar dan memancarkan keindahan.

4.Wisata digital dengan tema Negeri di Atas Awan, wisata digital ini menggunakan kapas dan kain yang menggambarkan seolah-olah pengunjung sedang berada di atas awan.

5.Wisata digital dengan tema Negara Belanda, wisata digital ini menggunakan pernak pernik negara belanda yaitu pakaian khas belanda, kincir angin, dan replika negara belanda. 6.Wisata digital dengan tema Rumah Pohon, wisata digital ini menggunakan bahan dasar kayu dan bambu yang dibuat menyerupai rumah pohon sehingga pengunjung dapat berswafoto.

7.Wisata digital dengan tema Rumah Jamur Kurcaci, wisata ini berbahan dasar stereofom yang dibentuk menyerupai rumah jamur dan dicat berwarna-warni

8. Wisata digital dengan tema Rumah Terbang, wisata digital ini mempunyai bentuk rumah panggung dengan ketinggian tertentu sehingga seolah-olah menjadi rumah terbang.

9.Wisata digital berkonsep Belanda, wisata digital ini mengadopsi segala sesuatu khas Belanda.

10.Wisata digital dengan tema Dunia Lampu Romantis, wisata digital ini menggunakan banyak lampu dan umumnya rame pada saat sore hari.

Salah satu tema wisata digital balon udara. 


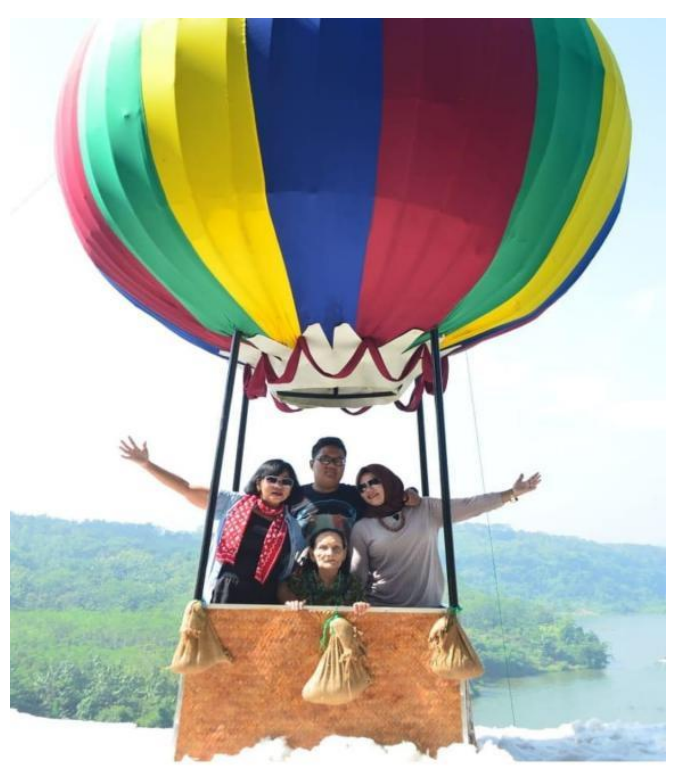

Sumber : Dokumentasi pribadi

Desa wisata Kandri selain wisata digital yang ditawarkan juga terdapat usaha UMKM yang terdiri lebih dari 25 pelaku UMKM, pelaku UMKM di desa wisata Kandri terdiri dari para pelaku usaha makanan ringan sampai dengan kerajinan tangan (https://kandri.semarangkota.go.id/, diakses 21 Juni 2021). Menurut (Maheswara et al, 2016) menyatakan bahwa upah dan modal yang ada di UMKM mempunyai pengaruh secara positif dan signifikan dengan kuantitas penjualan dimana dengan tingkat pendidikan pelaku UMKM serta jam kerja juga mempunyai pengaruh akan tetapi tidak signifikan. Tingkat pendidikan yang berpengaruh negatif tetapi tidak berpegaruh secara signifikan terhadap pendapatan UMKM. Adapun besar dan kecilnya jumlah penghasilan yang dialami oleh pelaku UMKM tergantung kepada tingkat upah kerja serta bonus yang diberikan sehingga menyebabkan pekerja menjadi lebih bermotivasi dalam melakukan pekerjaan. Melakukan pelatihan serta sosialisasi kepada pekerjadapat meningkatkan kualitas mutu sumberdaya manusia serta dapat meningkatkan penjualan. Selain itu dengan adanya beragam UMKM diharapkan pelaku UMKM dapat lebih berinovasi dan mengembangkan kreativitasnya sesuai dengan selera pasar. Sejalan dengan pernyataan (Putri, 2016) yang mengatakan bahwa modal juga berpengaruh terhadap keberlangsungan usaha, pelaku UMKM yang memiliki modal besar juga turut andil dalam pengembangan usahanya, akan tetapi besaran modal yang ada belum dapat mendukung seluruh kegiatan operasional sehingga diperlukan bantuan pinjaman dari perbankan untuk mengembangkan usahanya. Adapun lokasi usaha juga turut berperan penting dalam mendapatkan permodalan. Pihak perbankan akan melihat laporan keuangan yang menjadi salah satu syarat dalam mendapatkan bantuan modal. Lokasi usaha dan pinjaman juga mempunyai pengaruh yang positif serta signifikan terhadap jumlah penghasilan UMKM, dengan kata lain pemberian pinjaman perbankan akan mempengaruhi dalam hal pendapatan dengan memperluas jenis usaha pelaku UMKM.

Prakosa dan Sumatika, 2018 menyatakan bahwa organisasi berorientasi kepada pasar yang berorientasi kepada pelanggannya dapat bertahan di saat persaingan dan perubahan. Orientasi pasar bukanlah faktor utama, namun orientasi bisnis seorang wirausahawan dapat melengkapi usahanya dengan tujuan yang lebih jelas. Jika organisasi 
bisnis mampu mengenali pelanggan, pelanggan akan dengan mudah memberikan layanan terbaik. Keputusan pemasaran strategis seperti menentukan segmen mana yang akan ditawarkan, menargetkan pasar, dan memposisikan produk di benak konsumen lebih mudah dipahami oleh organisasi perusahaan yang berorientasi pasar dan bisnis, sedangkan Sumantika dan Prakosa, 2019 mengatakan bahwa berdasarkan hasil analisis menyimpulkan bahwa wanita lebih produktif daripada pria dalam performa bisnis, akan tetapi berdasarkan uji yang telah dilakukan bahwa tidak terdapat perbedaan kinerja perusahaan yang signifikan sebesar antara laki-laki dan perempuan serta menunjukkan bahwa tidak ada perbedaan yang signifikan dalam kinerja yang tergantung tingkat pendidikan responden. Peran pemerintah daerah dalam mempromosikan produk olahan hasil UMKM sehingga terjadi peningkatan volume usaha produksi serta dapat meningkatkan pendapatan pelaku UMKM, umumnya pendapatan yang diperoleh dengan berjualan makanan ringan siap saji. Faktor yang berpengaruh salah satunya adalah lokasi pemasaran yang luas serta mudah dijangkau dengan tetap memperhatikan modal yang diperoleh baik dari bantuan pemerintah maupun pinjaman dari lembaga keuangan atau perbankan (Gita dan Sukarsa, 2013). Tujuan penelitian untuk mengetahui performa bisnis yang berdasarkan pada karakteristik responden yang terdiri atas jenis kelamin, tingkat pendidikan serta usia di Desa wisata Kandri Semarang.

\section{METODE}

Penelitian yang dilakukan di Desa wisata Kandri Semarang menggunakan metode purposive sampling, sedangkan untuk teknik analisis data kuantitatif merupakan langkah dalam memperoleh data, sehingga dengan mengetahui teknik pengumpulan mata, maka data yang akan didapatkan dapat memenuhi standar. Penelitian yang dilakukan merupakan bentuk penelitian komparasi dengan melihat adanya persamaan maupun perbedaan mengenai dua atau lebih kejadian yang terjadi dengan melihat apa yang menjadi penyebabnya. Data yang telah dikumpulkan baik berdasarkan jenis maupun sumber data. Teknik data yang digunakan pada penelitian ini dengan menggunakan kuesioner. Kuesioner yang dikumpulkan merupakan salah satu langkah mengumpulkan dara yang dilakukan dengan memberikan pernyataan atau pertanyaan yang dilakukan secara tertulis kepada responden, dimana responden tersebut akan menjawab pertanyaan tersebut (Sugiyono, 2010). Adapun pemberian kuesioner kepada responden dilakukan secara langsung dimana pemberian kuesioner tersebut telah memenuhi seluruh aspek komponen diantaranya komponen konteks, masukan, proses serta hasil penelitian tersebut.

Skala likert yang digunakan pada pengukuran bertujuan untuk mengklasifikasikan variabel yang diharapkan hasil pengukuran tidak terdapat kesalahan sehingga tepat dalam menentukan analisis data serta langkah selanjutnya dalam penelitian. Adapun prinsip pokok dalam skala likert yaitu menentukan bagaimana kedudukan responden menentukan objek sifat dari mulai sangat positif sampai dengan sangat negatif. Adapun pembuatan alat ukur dengan skala 5, adapun jawaban yang dijadikan skala pengukuran adalah Sangat Setuju (SS), Setuju (S), Cukup Setuju (CS), Tidak Setuju (TS) dan Sangat Tidak Setuju (STS), pada masing-masing pertanyaan mempunyai bobot nilai 1 untuk sangat tidak setuju sampai dengan nilai 5 untuk option sangat setuju. Jumlah sampel pada penelitian ini pada seluruh UMKM yang ada di desa wisata Kandri dengan jumlah responden 50 pelaku UMKM. Variabel penelitian berupa variabel dependent dan independen. Variabel dependent yang diuji adalah perfoma bisnis UMKM di desa wisata Kandri. Variabel independent yang 
diteliti adalah jenis kelamin (Laki-laki dan perempuan), jenjang pendidikan dari Sekolah Dasar sampai perguruan tinggi, dan usia dari 20 tahun sampai lebih dari 50 tahun dengan pengelompokkan menjadi 4 rentang usia. Peneliti mengambil seluruh sampel dengan menggunakan skala likert dengan memberikan pertanyaan kualitatif yang menggambarkan performa bisnis pelaku UMKM adalah sebagai berikut:

1. Pertanyaan 1 yaitu pemilik usaha mendapatkan penghasilan bersih yang terus meningkat seiring dengan bertambahnya waktu

2. Pertanyaan 2 yaitu pemilik usaha melihat perkembangan usaha yang terus meningkat

3. Pertanyaan 3 yaitu pemilik usaha memberikan pelayanan yang baik kepada pelanggan

4. Pertanyaan 4 yaitu pemilik usaha mampu mengembalikan modal awal investasi

5. Pertanyaan 5 yaitu pemilik usaha mampu mempertahankan konsumen yang loyal

Seluruh sampel yang telah didapatkan kemudian peneliti melakukan 3 uji yaitu uji instrumen yang terdiri dari uji validitas dan uji reliabilitas, uji homogenitas dan uji dengan menggunakan ANOVA satu arah (one way ANOVA). ANOVA satu arah digunakan untuk menguji perbandingan diantara beberapa kelompok data dengan menggunakan skor ratarata. Analisis varian merupakan suatu bentuk analisis data untuk mengetahui perbedaan skor antara dependent variable yang disebabkan oleh perbedaan skor independent variable. Teknik analisis data menggunakan bantuan SPSS 24 for windows, sebelum dilakukan pengujian One Way ANOVA perlu dilakukan uji instrumen, uji normalitas data dan uji homogenitas. Uji normalitas sebaran data bertujuan untuk mendapatkan kenormalan distribusi sebaran independent variable skor. Skor signifikansi menunjukkan nilai lebih besar atau sama dengan 0,05 maka dapat disimpulkan bahwa data tersebut berdistribusi normal sedangkan apabila signifikansi kurang dari 0,05 maka data yang didapatkan tidak berdistribusi normal, sedangkan uji instrumen terhadap 50 sampel yang diambil dengan menguji validitas setiap butir pertanyaan dan uji reliabilitas. Uji validitas yang digunakan sebagai parameter bahwa setiap pertanyaan adalah valid dengan nilai $r$ hitung lebih besar dari $r$ tabel $(0,279)$. Uji realibilitas dengan menggunakan cornbach alpha dimana nilai harus lebih besar dari 0,6 sebagai syarat reliabel. Terdapat 3 hipotesis yang akan diuji antara lain

Hipotesis 1 : terdapat perbedaan antara performa bisnis dengan perbedaan jenis kelamin Hipotesis 2 : terdapat perbedaan antara performa bisnis dengan perbedaan usia Hipotesis 3 : terdapat perbedaan antara performa bisnis dengan tingkat pendidikan

\section{HASIL DAN PEMBAHASAN}

Penelitian dilakukan di desa wisata Kandri Semarang dengan menggunakan data purposive sampling kepada para pelaku UMKM yang ada di desa wisata Kandri. Para pelaku UMKM terdiri dari wisata digital serta makanan ringan dan kerajinan tangan. Data responden disajikan pada tabel 1 yang menunjukkan bahwa data yang diambil meliputi karakteristik responden yang akan diuji berdasarkan jenis kelamin, usia serta tingkat pendidikan. Data yang diambil sebanyak 50 responden pelaku UMKM yang terdiri atas lakilaki dan perempuan, dengan rentang usia antara 20 sampai dengan lebih dari 50 tahun, sedangkan tingkat pendidikan pelaku UMKM menunjukkan bahwa mayoritas pelaku usaha UMKM adalah lulusan SMA dengan usia terbanyak pada kisaran 31-40 sebanyak 20 responden. Data mengenai karakteristik responden dapat dilihat pada tabel 1. 
Tabel 1. Data responden

\begin{tabular}{lclllr}
\hline \multicolumn{2}{c}{ Jenis Kelamin } & \multicolumn{2}{c}{ Usia } & \multicolumn{2}{c}{ Tingkat Pendidikan } \\
\hline JK & Total & Usia & Total & TP & Total \\
\hline Laki-Laki & 22 & $20-30$ & 8 & SD & 3 \\
\hline Perempuan & 28 & $31-40$ & 20 & SMP & 7 \\
\hline & & $41-50$ & 18 & SMA & 36 \\
\hline \multicolumn{2}{l}{} & $>50$ & 4 & S1/S2 & 4 \\
\hline Total Sampel & 50 & Total Sampel & 50 & Total Sampel & 50 \\
\hline
\end{tabular}

Sumber : Hasil olah data primer

\section{Uji instrumen data}

Sampel yang akan digunakan pada uji validitas dan uji reliabilitas sebanyak 50 responden yang dapat di lihat pada tabel 2 .

Tabel 2. Uji validitas dan Uji Reliabilitas

\begin{tabular}{cccc}
\hline Variabel & Butir & Rtabel & Rhitung \\
\hline \multirow{3}{*}{ Performa Bisnis } & 1 & 0,740 & 0,279 \\
\cline { 2 - 4 } & 2 & 0,708 & 0,279 \\
\cline { 2 - 4 } & 3 & 0,771 & 0,279 \\
\cline { 2 - 4 } & 4 & 0,697 & 0,279 \\
\hline Cornbach Alpha & 5 & 0,592 & 0,279 \\
\hline
\end{tabular}

Sumber : Hasil olah data primer

Pada tabel 2 menunjukkan bahwa butir pertanyaan sebanyak 5 pertanyaan performa bisnis mempunyai nilai yang valid. Nilai $r$ hitung lebih besar dari $r$ tabel sehingga menunjukkan korelasi yang positif dengan nilai cornbach alpha sebesar 0,820 atau dapat dikatakan reliabel karena mempunyai nilai yang lebih besar dari 0,6

\section{Uji Normalitas Data}

Uji normalitas yang dilakukan terhadap sampel data merupakan salah satu syarat dalam analisis data. Uji normalitas dilakukan untuk mengetahui kenormalan data yang akan diuji dengan menggunakan skor pada skala likert, analisis data dengan menggunakan bantuan SPSS 24 for windows dengan kriteria pengujian yaitu dengan taraf signifikansi $(\alpha=0,05)$ yaitu apabila sig $>0,05$ maka Ho diterima sedangkan apabila nilai sig $<0,05$ maka Ho ditolak. Adapun hasil pengujian normalitas data performa bisnis pelaku UMKM dapat dilihat pada tabel 3 .

Tabel 3. Uji Normalitas

\begin{tabular}{llr}
\hline & & $\begin{array}{c}\text { Unstandardized } \\
\text { Residual }\end{array}$ \\
\hline $\mathrm{N}$ & & 50 \\
\hline Normal Parameters $^{\mathrm{a}, \mathrm{b}}$ & Mean &, 0000000 \\
& Std. Deviation & 3,10446273 \\
\hline Most Extreme Differences & Absolute &, 080 \\
& Positive &, 071 \\
& Negative &,- 080 \\
\hline Test Statistic & &, 080 \\
\hline Asymp. Sig. (2-tailed) & &, $200^{\mathrm{c}, \mathrm{d}}$ \\
\hline
\end{tabular}


a. Test distribution is Normal.

b. Calculated from data.

c. Lilliefors Significance Correction.

d. This is a lower bound of the true significance.

Sumber : Hasil olah data primer

Pada tabel 3. didapatkan hasil uji normalitas data Adapun hasil pengujian normalitas data performa bisnis pelaku UMKM dapat dilihat pada tabel 1. menunjukkan bahwa nilai untuk uji normalitas Kolmogorov-Smirnov3 mempunyai nilai sig 0,200, Sesuai dengan pengujian hipotesis bahwa apabila sig> 0,05 maka Ho diterima sedangkan apabila nilai sig $<0,05$ maka Ho ditolak, sehingga dapat disimpulkan bahwa data hasil uji normalitas performa bisnis pelaku UMKM adalah berdistribusi normal.

\section{Uji Homogenitas data}

Uji homogenitas data pada performa bisnis UMKM menunjukkan bahwa kedua responden menunjukkan data yang berdistribusi normal sehingga uji homogenitas ini diujikan untuk mengetahui apakah kedua kelompok data memiliki perbedaan atau persamaan. Perhitungan uji homogenitas data performa bisnis menggunakan bantuan SPSS 24.0 for windows. Hipotesis yang akan diuji pada data tersebut yaitu : H0 apabila tidak terdapat variansi antara kelompok data sampel (homogen) dan H1 apabila terdapat perbedaan antara kelompok data sampel (tidak homogen). Adapun kriteria pengujian yaitu dengan taraf signifikansi $(\alpha=0,05)$ yaitu apabila sig> 0,05 maka Ho diterima sedangkan apabila nilai sig $<0,05$ maka Ho ditolak. Adapun hasil pengujian homogenitas data performa bisnis dapat dilihat pada tabel 4 .

Tabel 4 Hasil Uji Homogenitas data

\begin{tabular}{ccccc}
\hline & Levene Stat & df1 & df2 & Sig. \\
\hline Jenis Kelamin & 1,779 & 5 & 42 &, 138 \\
\hline Usia & 1,197 & 5 & 42 &, 962 \\
\hline Tingkat Pendidikan & 1,307 & 5 & 42 &, 279 \\
\hline
\end{tabular}

Sumber : Hasil olah data primer

Pada tabel 4 menunjukkan bahwa hasil uji homogenitas data menunjukkan nilai sig di atas 0,05 , sehingga dapat disimpulkan bahwa $\mathrm{H} 0$ diterima, karena nilai yang didapatkan pada Levene Statistic menunjukkan homogenitas sampel data lebih besar dari $\alpha=0,05$ sehingga tidak terdapat perbedaan variansi antara dua kelompok data tersebut, atau dapat diartikan bahwa data tersebut adalah homogen. Pada uji homogenitas yang meliputi jenis kelamin menunjukkan bahwa levene statistic menunjukkan 1,779 dengan nilai signifikansi 0,138 , sedangkan pada data usia diperoleh nilai levene statistic pada angka 1,197 dengan nilai signifikansi 0,962 . Uji homogenitas pada tingkat pendidikan menunjukkan levene statistic 1,307 dengan nilai signifikansi 0,279.

4. Deskriptif

A. Pengujian hipotesis pertama 
Hipotesis 1 : terdapat perbedaan antara performa bisnis dengan perbedaan jenis kelamin. Pada tabel 5 menunjukkan bahwa descriptives data performa bisnis pada laki-laki lebih tinggi apabila dibandingkan dengan perempuan, hal ini terlihat pada nilai mean dari laki-laki 16,91 dan perempuan 16,36. Descriptives data menggambarkan rata-rata performa bisnis berdasarkan jenis kelamin yaitu laki-laki dan perempuan dapat dilihat pada tabel 5 .

Tabel 5. Descriptives Data

performa_bisnis

\begin{tabular}{lcccccccc} 
& \multicolumn{7}{c}{ Std. } & \multicolumn{2}{c}{ Std. } & \multicolumn{2}{c}{$95 \%$ Confidence Interval for Mean } & \\
& $\mathrm{N}$ & Mean & Dev & Error & Lower Bound & Upper Bound & Min & Max \\
\hline laki-laki & 22 & 16,91 & 3,069 &, 654 & 15,55 & 18,27 & 12 & 22 \\
\hline perempuan & 28 & 16,36 & 3,188 &, 602 & 15,12 & 17,59 & 10 & 21 \\
\hline Total & 50 & 16,60 & 3,117 &, 441 & 15,71 & 17,49 & 10 & 22 \\
\hline \multicolumn{7}{c}{ Sumber : Hasil olah data primer }
\end{tabular}

Pada tabel 5 menunjukkan bahwa descriptives data performa bisnis pada laki-laki lebih tinggi apabila dibandingkan dengan perempuan, hal ini terlihat pada nilai mean dari laki-laki 16,91 dan perempuan 16,36.

Tabel 6. ANOVA Hasil Uji Hipotesis Pertama

\begin{tabular}{lccccr} 
performa_bisnis & \multicolumn{1}{c}{} & & \\
& Sum of Squares & df & Mean Square & F & Sig. \\
\hline Between Groups & 3,753 & 1 & 3,753 &, 381 &, 540 \\
\hline Within Groups & 472,247 & 48 & 9,838 & & \\
\hline Total & 476,000 & 49 & & & \\
\hline \multicolumn{5}{c}{ Sumber : Hasil olah data primer }
\end{tabular}

Pada tabel 6. hasil uji hipotesis pertama dengan menggunakan one way ANOVA menunjukkan bahwa tidak terdapat perbedaan antara performa bisnis dengan jenis kelamin, hal ini ditunjukkan bahwa nilai signifikansi sebesar 0,540 lebih besar dari 0,05 sehingga hipotesis pertama dinyatakan DITOLAK.

B. Pengujian hipotesis kedua

Hipotesis 2 : terdapat perbedaan antara performa bisnis dengan perbedaan usia

\section{Tabel 7. Descriptives Data}

performa_bisnis

\begin{tabular}{|c|c|c|c|c|c|c|c|c|}
\hline & \multirow[b]{2}{*}{$\mathrm{N}$} & \multirow[b]{2}{*}{ Mean } & \multirow{2}{*}{$\begin{array}{l}\text { Std. } \\
\text { Dev }\end{array}$} & \multirow{2}{*}{$\begin{array}{c}\text { Std. } \\
\text { Error }\end{array}$} & \multicolumn{2}{|c|}{$95 \%$ Confidence Interval for Mean } & \multirow[b]{2}{*}{ Min } & \multirow[b]{2}{*}{ Max } \\
\hline & & & & & Lower Bound & Upper Bound & & \\
\hline $20-30$ & 8 & 20,88 &, 835 & ,295 & 20,18 & 21,57 & 20 & 22 \\
\hline $31-40$ & 20 & 17,00 & 2,513 & ,562 & 15,82 & 18,18 & 13 & 21 \\
\hline
\end{tabular}




\begin{tabular}{lcccccccc}
\hline $41-50$ & 18 & 17,50 & 1,291 &, 645 & 15,45 & 19,55 & 16 & 19 \\
\hline$>50$ & 4 & 14,06 & 2,127 &, 501 & 13,00 & 15,11 & 10 & 17 \\
\hline Total & 50 & 16,60 & 3,117 &, 441 & 15,71 & 17,49 & 10 & 22 \\
\hline
\end{tabular}

Sumber : Hasil olah data primer

Pada tabel 7 menunjukkan bahwa descriptives data performa bisnis pada rentang usia yaitu 20-30, 31-40, 41-50 dan lebih dari 50 menunjukkan bahwa performa bisnis usia 2030 lebih tinggi apabila dibandingkan dengan ketiga rentang usia lainnya, sementara rentang usia lebih dari 50 menunjukkan nilai mean yang lebih rendah apabila dibadingkan dengan ketiga rentang usia yang lain. Nilai mean dari descriptives data tersebut antara lain usia 2030 tahun dengan nilai mean 20,88, usia 31-40 mempunyai nilai mean 17,00 sedangkan usia 41-50 mempunyai nilai mean 17,50 dan usia lebih dari 50 mempunyai nilai mean 14,06. Descriptives data di atas menggambarkan rata-rata performa bisnis berdasarkan rentang usia pelaku UMKM di desa wisata Kandri Semarang.

Tabel 8. ANOVA Hasil Uji Hipotesis Kedua

\begin{tabular}{lrrrrr} 
performa_bisnis & \multicolumn{1}{c}{} & & \\
& Sum of Squares & df & Mean Square & F & Sig. \\
\hline Between Groups & 269,181 & 3 & 89,727 & 19,957 &, 511 \\
\hline Within Groups & 206,819 & 46 & 4,496 & & \\
\hline Total & 476,000 & 49 & & & \\
\hline
\end{tabular}

Sumber : Hasil olah data primer

Pada tabel 8. hasil uji hipotesis kedua dengan menggunakan one way ANOVA menunjukkan bahwa tidak terdapat perbedaan antara performa bisnis dengan usia responden, hal ini ditunjukkan bahwa nilai signifikansi sebesar 0,511 lebih besar dari 0,05 sehingga hipotesis kedua dinyatakan DITOLAK.

C. Pengujian Hipotesis Ketiga

Hipotesis 3 : terdapat perbedaan antara performa bisnis dengan tingkat pendidikan

Tabel 9. Descriptives Data

performa_bisnis

\begin{tabular}{|c|c|c|c|c|c|c|c|c|}
\hline & \multirow[b]{2}{*}{$\mathrm{N}$} & \multirow[b]{2}{*}{ Mean } & \multirow{2}{*}{$\begin{array}{l}\text { Std. } \\
\text { Dev }\end{array}$} & \multirow{2}{*}{$\begin{array}{l}\text { Std. } \\
\text { Error }\end{array}$} & \multicolumn{2}{|c|}{ 95\% Confidence Interval for Mean } & \multirow[b]{2}{*}{ Min } & \multirow[b]{2}{*}{ Max } \\
\hline & & & & & Lower Bound & Upper Bound & & \\
\hline SD & 3 & 15,75 & 2,912 & ,485 & 14,76 & 16,74 & 10 & 21 \\
\hline SMP & 7 & 17,71 & 2,812 & 1,063 & 15,11 & 20,31 & 14 & 21 \\
\hline SMA & 36 & 19,00 & 2,160 & 1,080 & 15,56 & 22,44 & 17 & 22 \\
\hline $\mathrm{S} 1 / \mathrm{S} 2$ & 4 & 21,00 & 1,000 &, 577 & 18,52 & 23,48 & 20 & 22 \\
\hline Total & 50 & 16,60 & 3,117 & ,441 & 15,71 & 17,49 & 10 & 22 \\
\hline
\end{tabular}

Sumber : Hasil olah data primer 
Pada tabel 9 menunjukkan bahwa descriptives data performa bisnis pada tingkat pendidikan yaitu terdiri dari 4 tingkatan antara lain SD, SMP, SMA, S1/S2 yang menunjukkan bahwa performa bisnis tingkat pendidikan sarjana (S1/S2) menunjukkan performa bisnis lebih tinggi apabila dibandingkan dengan ketiga rentang usia lainnya, sementara tingkat pendidikan SD menunjukkan nilai mean yang lebih rendah apabila dibadingkan dengan ketiga rentang usia yang lain. Nilai mean dari descriptives data tersebut antara lain SD mempunyai nilai mean 15,75 , jenjang SMP mempunyai nilai mean 17,71 , jenjang SMA mempunyai nilai Mean 19,00 dan jenjang sarjana S1/S2 mempunyai nilai mean 21. Descriptives data di atas menggambarkan rata-rata performa bisnis berdasarkan tingkat pendidikan pelaku UMKM di desa wisata Kandri Semarang.

Tabel 10. ANOVA Hasil Uji Hipotesis Ketiga

\begin{tabular}{lrrrrr}
\hline performa_bisnis & \multicolumn{1}{c}{ Sum of Squares } & df & Mean Square & F & \multicolumn{1}{c}{ Sig. } \\
\hline Between Groups & 115,821 & 3 & 38,607 & 4,931 &, 555 \\
\hline Within Groups & 360,179 & 46 & 7,830 & & \\
\hline Total & 476,000 & 49 & & & \\
\hline
\end{tabular}

Sumber : Hasil olah data primer

Pada tabel 10. hasil uji hipotesis ketiga dengan menggunakan one way ANOVA menunjukkan bahwa tidak terdapat perbedaan antara performa bisnis dengan tingkat pendidikan hal ini ditunjukkan bahwa nilai signifikansi sebesar 0,555 lebih besar dari 0,05 sehingga hipotesis ketiga dinyatakan DITOLAK.

\section{SIMPULAN}

Berdasarkan uji analisa data menunjukkan bahwa performa bisnis pada jenis kelamin laki-laki lebih tinggi apabila dibandingkan dengan perempuan dengan nilai mean 16,91. Setelah dilakukan uji one way ANOVA didapatkan hasil bahwa tidak terdapat perbedaan performa bisnis terhadap jenis kelamin. Hal ini ditunjukkan dengan nilai signifikansi 0,540. Berdasarkan descriptives Performa bisnis pada rentang usia yaitu 20-30, 31-40, 41-50 dan lebih dari 50 menunjukkan bahwa performa bisnis usia 20-30 lebih tinggi apabila dibandingkan dengan ketiga rentang usia lainnya dengan nilai mean 20,88, setelah dilakukan uji one way ANOVA menunjukkan bahwa tidak terdapat perbedaan antara performa bisnis dengan usia responden, hal ini ditunjukkan bahwa nilai signifikansi sebesar 0,511 . Hasil Pengujian pada descriptives data performa bisnis pada tingkat pendidikan yaitu terdiri dari 4 tingkatan antara lain SD, SMP, SMA, S1/S2 yang menunjukkan bahwa performa bisnis tingkat pendidikan sarjana ( $1 / \mathrm{S} 2)$ menunjukkan performa bisnis lebih tinggi apabila dibandingkan dengan ketiga rentang usia lainnya dengan nilai nilai mean 21 , setelah dilakukan pengujian dengan menggunakan one way ANOVA menunjukkan bahwa 
tidak terdapat perbedaan antara performa bisnis dengan tingkat pendidikan, hal ini ditunjukkan bahwa nilai signifikansi sebesar 0,555 lebih besar dari 0,05. Analisa Performa Bisnis di Desa Wisata Kandri Semarang dengan menguji karakteristik Responden tidak menunjukkan perbedaan sehingga pengujian lebih lanjut dengan menambahkan beberapa variabel tambahan yang dapat diteliti seperti misalnya lama usaha, pengembangan usaha, ataupun data yang diambil lebih luas meliputi seluruh kota ataupun Kabupaten di Semarang atau kota sekitarnya.

\section{DAFTAR RUJUKAN}

Ardiana, I. D. K. R., Brahmayanti, I. A., \& Subaedi, S. (2010). Kompetensi SDM UMKM dan pengaruhnya terhadap kinerja UMKM di Surabaya. Jurnal manajemen dan Kewirausahaan, 12(1), pp-42.

Dewi, N. P. M., \& Utari, T. (2014). Pengaruh modal, tingkat pendidikan dan teknologi terhadap pendapatan usaha mikro kecil dan menengah (UMKM) di Kawasan Imam Bonjol Denpasar Barat. E-Jurnal Ekonomi Pembangunan Universitas Udayana, 3(12), 44496.

Gita, S. D., Putri, P., \& Sukarsa, I. (2013). Pengaruh Harga Canang dan Pendapatan Konsumen Terhadap Permintaan Canang di Desa Sanur. Jurnal Ekonomi Pembangunan, 2(3), 142-151.

Hasanah, R. L., Kholifah, D. N., \& Alamsyah, D. P. (2020). Pengaruh modal, tingkat pendidikan dan teknologi terhadap pendapatan umkm di kabupaten purbalingga. Kinerja, 17(2), 305-313.

https://kandri.semarangkota.go.id/, diakses 21 Juni 2021

Kementerian Pariwisata. (2019). Buku Panduan Program Pengembangan Desa Wisata Berbasis Pendampingan melalui PT. Asdep Pengembangan SDM Pariwisata.

Maheswara, A. A. N. G., Setiawarna, N. J., \& Saskara, I. A. N. (2016). Analisis faktorfaktor yang mempengaruhi pendapatan UMKM sektor perdagangan di Kota Denpasar. E-Jurnal Ekonomi dan Bisnis Universitas Udayana, 5(2016), 4271-4298.

Prakosa, A., \& Sumantika, A. (2018). Market Orientation, Entrepreneurial Orientation dan Business Performance pada Usaha Mikro Kecil di Desa Wisata Daerah Istimewa YOGYAKARTA. Jurnal Manajemen, 8(1), 36-45.

Putri, N. M. D. M., \& Jember, I. (2016). Pengaruh modal sendiri dan lokasi usaha terhadap pendapatan Usaha Mikro Kecil Menengah (UMKM) di Kabupaten Tabanan (modal pinjaman sebagai variabel intervening). Jurnal Ekonomi Kuantitatif Terapan, 9(2), $142-150$. 
Rahayu Kurniawan. 2011. Pengembangan Kopetensi Sumber Daya Manusian Dan Bantuan Modal Di Kabupaten Jepara.Skripsi.Universitas Negeri Semarang.

Septemuryantoro, S. A. (2017). Potensi Wisata Budaya Jalur Gula dalam Menunjang Kenaikan Kunjungan Tamu Hotel di Kota Semarang. LITE: Jurnal Bahasa, Sastra, dan Budaya, 13(2), 174-194.

Septemuryantoro, S. A. (2020). Pengembangan Potensi Budaya Ekowisata melalui Pemberdayaan Masyarakat Desa Wisata Candirejo Borobudur Jawa Tengah. Media Wisata, 18(2), 210-222.

Sugiyono. 2010. Metode Penelitian Pendidikan Pendekatan Kuantitatif, kualitatif, dan R\&D. Bandung: Alfabeta

Sumantika, A., \& Prakosa, A. (2019). ANALISIS BUSINESS PERFORMANCE BERDASARKAN KARAKTERISTIK RESPONDEN: JENIS KELAMIN, TINGKAT PENDIDIKAN DAN USIA STUDI DI DESA WISATA DAERAH ISTIMEWA YOGYAKARTA. Optimum: Jurnal Ekonomi dan Pembangunan, 9(2), 115-123.

Undang - undang Nomor.20 Tahun 2008 Tentang Usaha Mikro Kecil Menengah, Jakarta. 